\title{
Poznań Air Pollution Analysis for 2015-2017
}

\author{
Anna Smurzyńska1 ${ }^{*}$, Wojciech Czekała1 , Piotr Hektus², Stanisław Marks', \\ Jakub Mazurkiewicz' ${ }^{1}$,Michał Brzoski', Dawid Chełkowski', Kamil Kozłowski' \\ 1 Poznań University of Live Sciences, Faculty of Biosystem Engineering, ul. Wojska Polskiego 50, 60-637 Poznań, \\ Poland \\ 2 Adam Mickiewicz University in Poznań, Faculty of Socio-economic Geography and Spatial Economy, \\ Krygowskiego 10, 61-680 Poznań, Poland \\ * Corresponding author's e-mail: a.smurzynska@gmail.com
}

\begin{abstract}
Air pollution is the result of natural processes and intense urban development. The undesired emission of volatile substances causes environmental threats such as acid rains, aggravated greenhouse effect or the ozone depletion. Moreover, the pollution released into the air is harmful to the human respiratory system, eyes and skin. This paper presents the body of analyses conducted in Poznań between 2015-2017 on the changes in the local emission concentration of PM10 and PM2.5. The data concerning the emission of suspended particulates were provided by the meteorological station on Polanka St. in Poznań. The research included a correlation analysis. The results point to a steady decrease in the amount of produced particulates. It was also noted that the emissions of PM10 and PM2.5 change seasonally, with the highest levels in the autumn and winter. Furthermore, the amount of emitted suspended particulates is correlated with the temperature; hence, it is supposed that the main source of air pollution in Poznan involves low-efficiency heaters and boilers.
\end{abstract}

Keywords: Poznań, air pollution, PM10, PM2.5

\section{INTRODUCTION}

As the industry develops and the urbanization continues, we note the tremendous influence of advanced civilization on the natural environment. Further development results in both technological advancement and the degradation of the natural environment. The main threat is the air pollution, which is a global problem, prevalent especially in the developed and developing countries [Cembrzyńska et al. 2012]. The air is polluted by gas, liquid, and solid substances in the form of suspended particulates (PM10, PM2.5). Table 1 presents the maximum accepted levels, the information threshold and the alarm levels for air pollution [Regulation of the Minister of the Environment ... 2012].

The sources of air pollution are divided into natural and anthropogenic. The natural sources include biological processes, volcanic eruptions, forest fires and lightning discharges. The anthropogenic pollution, on the other hand, results from the natural population growth and from the development of technology and industry. These sources can be divided into the pollution generated by the industry, traffic, energy sector and municipal waste. In the case of the industry, one should especially consider the consequences of the heavy, chemical and food industries [Dreiseidler et al. 2000]. The transportation is also an important branch of the industry affecting the air pollution [Roy et al. 2013]. Large cities are mostly affected by the car exhaust; therefore, the highest pollution is most often observed near the busy streets [McDonald et al. 2013]. The vehicles with diesel engines produce most nitrogen oxide emissions. The energy sector is the next significant source of air pollution, resulting from, among others, the usage of low-efficiency heaters in the households. Coal boilers and burning of waste and dry plant 
Table 1. Maximum acceptable levels, the information threshold and the alarm levels for air pollution, considering the protection of humans and plants $\left[\mu \mathrm{g} / \mathrm{m}^{3}\right]$

\begin{tabular}{|l|c|c|c|c|c|c|}
\hline \multicolumn{1}{|c|}{ Specification } & $\mathrm{NO}_{2}$ & $\mathrm{SO}_{2}$ & $\mathrm{O}_{3}$ & $\mathrm{C}_{6} \mathrm{H}_{6}$ & $\mathrm{PM} 2.5$ & $\mathrm{PM} 10$ \\
\hline Maximum accepted level of the annual average concentration & 40 & - & - & 5 & 25 & 40 \\
\hline Maximum accepted level of the daily average concentration & - & $125^{2}$ & - & - & - & $50^{4}$ \\
\hline Maximum accepted level of the hourly concentration & $200^{1}$ & $350^{3}$ & - & - & - & 50 \\
\hline Information threshold & - & - & 180 & - & - & 200 \\
\hline Alarm level for the hourly concentration & 400 & 500 & 240 & - & - & - \\
\hline Alarm level for the daily concentration & - & - & - & - & - & 300 \\
\hline
\end{tabular}

waste is another significant source of pollution [Lelek et al. 2016]. Therefore, the air pollution is most frequently observed in large cities and urban areas. The municipal pollution, in turn, includes the emissions resulting from waste management in households and on farms.

The air pollution increases the risk of many diseases, especially the respiratory system diseases, such as lung cancer [Gładka and Zatoński 2016; Sosa et al. 2017]. It causes irritation of the respiratory tract as well as increases the risk of respiratory infections and asthmatic diseases [Kampa and Castanas 2008]. The air pollution may also result in the conjunctiva and skin irritation. Increased heart rate and lower fitness levels are also common adverse effects. The particulates with a diameter over 2.5 micrometers are absorbed in the upper and lower respiratory tracts and they can penetrate into the bloodstream. Similarly to the PM10 particulates, they can cause coughing, breathing difficulties and breathlessness, especially during the physical exercise.

Apart from the direct effect on the human health, another considerable threat related to the air pollution are acid rains, which are caused by nitrogen and sulphur oxides. Moreover, the air pollutants, after they settle on the ground, cause a wide range of negative effects, such as acidification and heavy metals contamination of the soil, waters, and vegetation [ $\mathrm{Du}$ et al. 2017]. These effects also directly impact the human life and health. The acidic pollution of waters is another example. Low $\mathrm{pH}$ levels of the water leads to the release of toxic heavy metals, most of them bioaccumulate in fish tissues. Besides the degradation of flora and fauna, we also observe the damage to the structure of buildings [Maeda et al. 2001].

Smog is particularly dangerous for the human health [Mishra 2017]. It is produced as a result of high levels of air pollution under specific weather conditions [Ma et al. 2012]. The acidic smog (London type) is created in high humidity in the air contaminated mainly by sulphur oxides, carbon monoxide, and coal dust. It is observed in the winter at the temperatures between -3 and $-5^{\circ} \mathrm{C}$. The pollutants bind with the mist and create drops of sulphuric acid suspended in the air. This type of smog is dangerous to humans and animals, as well as the soil and water. It also causes damage to the structure of buildings. The London smog significantly limits the visibility (to several dozen meters). The photochemical smog (Los Angeles type) is produced in the period of increased emissions of peroxides and ozone, as well as nitrogen oxides, aldehydes, and aromatic hydrocarbons. It is usually observed in summer, at the temperatures over $+26^{\circ} \mathrm{C}$. In the sunlight, certain air pollutants react photochemically, creating carcinogenic toxic compounds which may also cause genetic mutations, for example, a poisonous gas created in the reaction of nitrogen oxides with hydrocarbons, i.e. peroxyacetyl nitrate (PAN). It is produced mainly in highly urbanized and densely populated areas [Wang et al. 2014]. The concentration of pollutants in the photochemical smog is usually extremely high and it significantly exceeds the accepted levels of air pollution recommended by WHO.

The ozone hole is the next danger linked to the air pollution. The increasing emissions of ozone and chlorofluorocarbons damage the protective ozone layer [Son et al. 2009]. As a result, the UV radiation permeates through the layer and it poses a serious threat to human and animal health, and even to the proper development of plants.

The air pollution aggravates the greenhouse effect, which is reported in the scientific research [Ramanathan and Feng 2009]. The climate change is a global problem affecting the proper functioning of flora and fauna.

In the face of the impending danger, multiple actions are taken to lower the emissions of gas and dust that are harmful to the environment. Biogas plants are one of the options that 
will not only allow to dispose of the harmful waste, but also produce energy (heating and/or electricity), which is crucial to the functioning of the urban areas [Cieślik et al. 2016; Czekała et al. 2016]. There are also other proposed methods of dangerous waste disposal for both the industrial and agricultural waste that produces harmful emissions [Smurzyńska et al. 2015; Czekała et al. 2017; Dzikuć 2017].

In consideration of the risks to the environment and the local community, linked to the pollutant emissions, an air quality analysis was conducted in Poznań. This is a large agglomeration, so it is at risk of the aforementioned industrial, traffic, energy and municipal air pollution. An analysis of changes in the emissions of PM10 and PM2.5 was conducted, as these particulates demonstrate a substantial risk to the human health. The research included the air quality measurements for the chosen agglomeration from 2015 to 2017.

\section{RESEARCH METHODOLOGY}

The data used consisted of the daily emissions of the suspended particulates: PM10 and PM2.5. The analyses included also the differences in the air temperatures. The research involved the measurements from 2015 to 2017 . The data were provided by the meteorological station on Polanka St. in Poznań.

The influence of the meteorological elements on the concentration of the pollutants was identified through the analysis of Pearson's correlation (r). The coefficient of variation $(\mathrm{V})$ was used to specify the changes in the concentration of the suspended particulates PM10 and PM2.5.

The research concerned the air pollution produced in Poznań, a city in west-central Poland with the surface of $262 \mathrm{~km}^{2}$ and a population of 540 thousand [SVS 2017].

\section{RESULTS AND DISCUSSION}

\section{Yearly concentration changes of PM10 and PM2.5}

In 2015, the daily maximum accepted level of the suspended particulate PM10 was exceeded 54 times. The median for this year was $27.5 \mu \mathrm{g} / \mathrm{m}^{3}$ (see Figure 1); $50 \%$ of all the cases fit in the concentration range between $18-41.5 \mu \mathrm{g} / \mathrm{m}^{3}$. The lowest recorded value was $7 \mu \mathrm{g} / \mathrm{m}^{3}$, whereas the highest was $168 \mu \mathrm{g} / \mathrm{m}^{3}$. The values for the year 2016 were similar to the previous year. The daily median of the concentration of the particulate PM10 was $29 \mu \mathrm{g} / \mathrm{m}^{3}$. The range for $50 \%$ of all

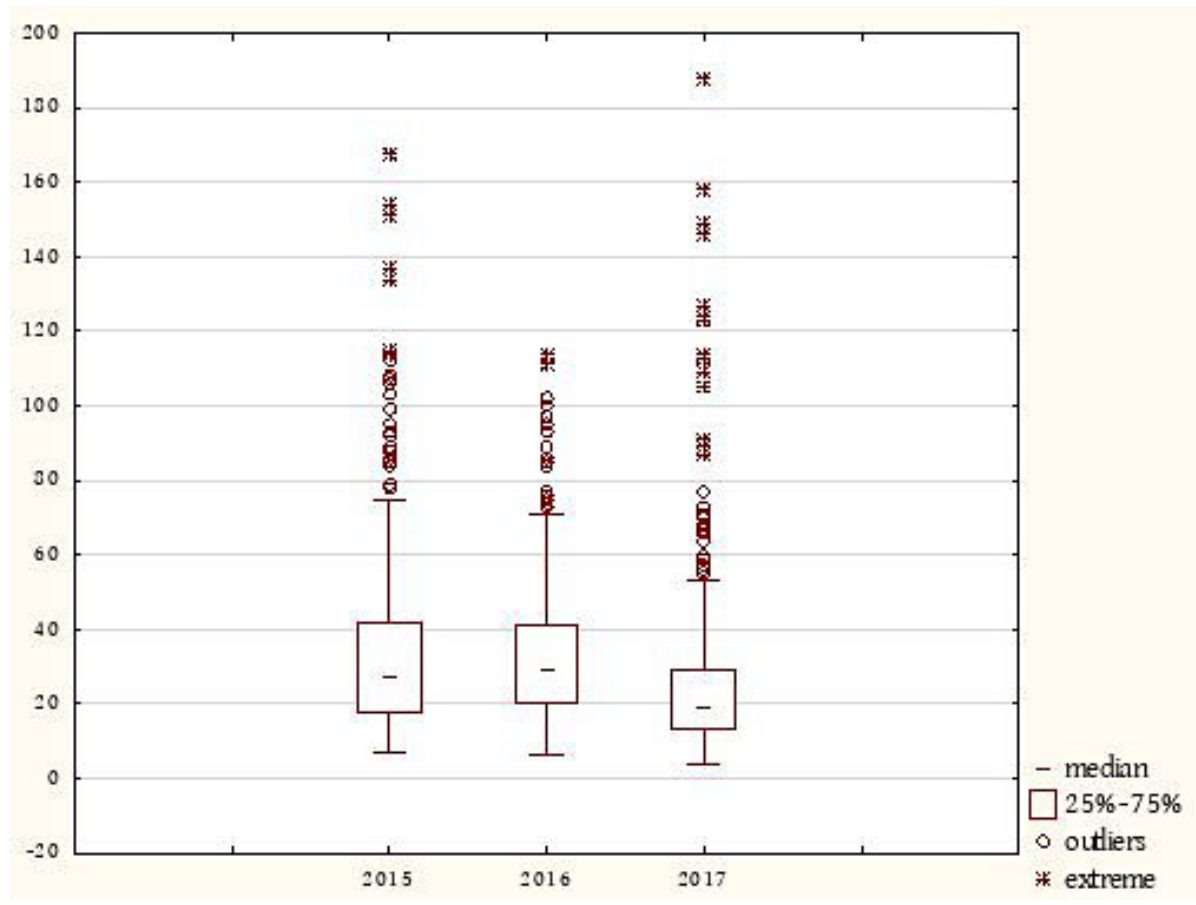

Figure 1. The concentration of the suspended particulate PM10 in the years 2015-2017 $\left[\mu \mathrm{g} / \mathrm{m}^{3}\right]$ - daily measurements (based on the data from the meteorological station on Polanka St. in Poznań) 
the cases was $20-41 \mu \mathrm{g} / \mathrm{m}^{3}$. In 2016 , less extreme values were recorded, with the highest daily concentration of $114 \mu \mathrm{g} / \mathrm{m}^{3}$, while the norm was exceeded 49 times. In 2017, a decrease of the daily concentration was noted for PM10 in comparison to the 2015-2016 period. The median for 2017 was $19 \mu \mathrm{g} / \mathrm{m}^{3}$. The value of the third quartile was close to the median for the previous years and it was $29 \mu \mathrm{g} / \mathrm{m}^{3}$. In 2017, the accepted norm was exceeded 35 times.

The changes in the daily concentrations of the suspended particulate PM2.5 for the years 2015-2017 are shown in Figure 2. It has been noted that in the analyzed years, the yearly concentration of PM2.5 did not show significant changes. The median for the analyzed years was respectively $14,16,15 \mu \mathrm{g} / \mathrm{m}^{3}$. The values for the first quartile were identical $-10 \mu \mathrm{g} / \mathrm{m}^{3}$. On this basis, it is concluded that the lower limit of the daily concentration of the particulate is relatively constant. The differences in the concentration of PM2.5 for the years 2015-2017 concern the third quartile and the outliers. The conclusion is that every year, there are days when the concentration value of the particulate PM2.5 is frequently exceeded, but the numbers of the outliers for the analysed years differ.

The sources of suspended particulate emissions are not only the volcano eruptions or forest fires, but in case of the Poznań agglomeration, it mainly involves the production processes. Poznań is an important centre of the car, food, pharmaceutical, chemical and machine industry. The leading producers on the national level are: Volkswagen Poznań Sp. z o.o. [Ltd.], Bridgestone Poland Sp. z o.o. [Ltd.], Exide Technologies SA [JSC], Kompania Piwowarska SA [JSC], Unilever Polska Sp. z o.o. [Ltd.], Wrigley Poland Sp. z o. o. [Ltd.], Wyborowa SA [JSC], Jutrzenka Colian Sp. z o.o. [Ltd.] facility in Poznań, Uniq Lisner Sp. z o.o. [Ltd.], Terravita Sp. z o.o. [Ltd.], Poznańska Palarnia Kawy Astra ${ }^{\circledR}$ Sp. z o.o. [Ltd.], Spółdzielnia Piekarsko-Ciastkarska "Fawor", GlaxoSmithKline Pharmaceuticals SA [JSC], Nivea Polska Sp. z o. o. [Ltd.], Przedsiębiorstwo Farmaceutyczne "Ziołolek" Sp. z o. o. [Ltd.], Poznańskie Zakłady Farmaceutyczne "Herbapol" SA [JSC], Grupa Kapitałowa H. Cegielski - Poznań SA [JSC], SKF Poznań SA [JSC]. The greatest amounts of the suspended particulates are produced by the industries such as energy, chemical, mining, metal producing and construction, as confirmed by the research on the coal energy industry by Wang et al. [2018]. In the case of Poznań, the air pollution with PM10 and PM2.5 is certainly heavily influenced by the energy production and the heating sector, as many installations require considerable investments to improve their condition [Mayer 1999].

The collected data suggest a gradual decrease in the emissions of PM10 and PM2.5 to the atmosphere, especially in 2017. It may be the result of the actions of the local authorities who promoted the idea of replacing private transport with the

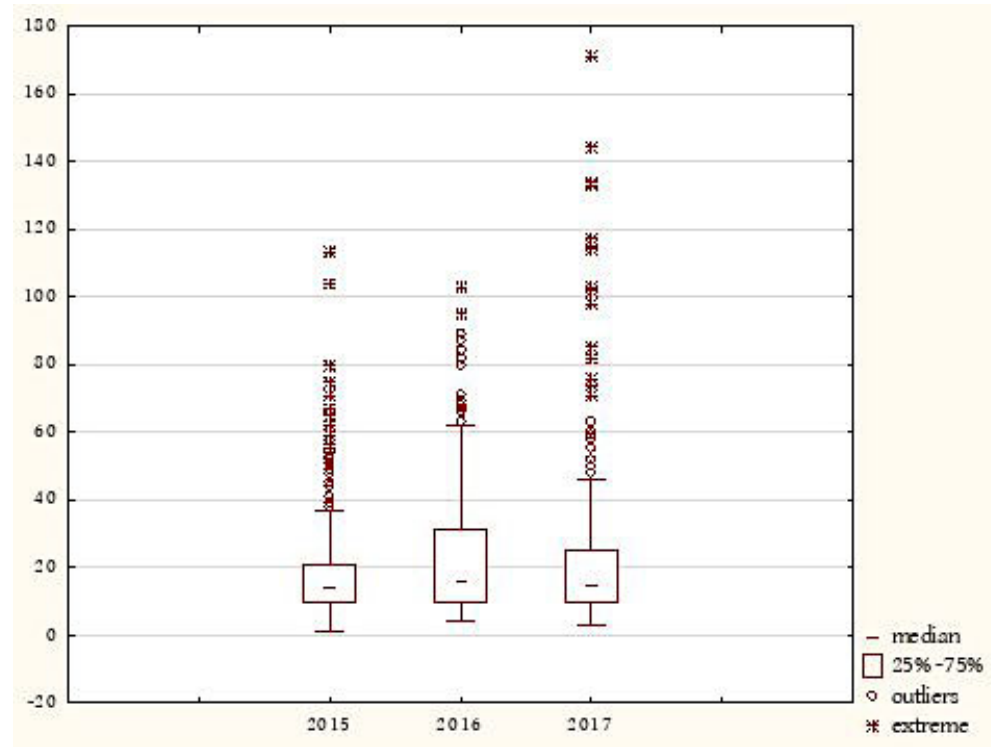

Figure 2. The concentration of the suspended particulate PM2.5 in the years 2015-2017 $\left[\mu \mathrm{g} / \mathrm{m}^{3}\right]$ - daily measurements

(based on data from the meteorological station on Polanka St. in Poznań) 
public transport and introduced a number of improvements (bus lanes) that made the public transport a more attractive means of transportation [Fajczak-Kowalska et al. 2017]. Free tram passes were offered to the inhabitants during the periods of heavy air pollution. Moreover, Poznań offers a well-developed train and tram network. A widespread use of the public transport can efficiently lower the air pollution with PM10 and PM2.5. On the other hand, the air and car transportation cause the PM10 and PM2.5 emissions [Penn et al. 2017]. In the researched urban area, there is an international airport, Poznań-Ławica, which generates massive emissions of air pollutants. According to the statistics for Poznań, the number of passenger cars is growing. In 2014, there were 601 vehicles per 1000 inhabitants, while in 2016, the number grew to 660 vehicles [SVS 2017]. Therefore, there are a number of proposed investments in the traffic infrastructure which may lower the air pollution in the long term. Some of them were previously implemented in China [Sun et al. 2018].

Within the KAWKA program, Poznań introduced subsidies for the replacement of the old heaters and coal boilers with the system heat, gas or electric heaters. It allowed to modernize many old, low-efficiency installations. Lower energy usage related to heating is also possible through thermo-modernisation of the public buildings, tenement houses and private houses.

Another significant factor which contributes to the regular decrease of the suspended particulates emissions is raising the public awareness of the issue [Environmental Protection Plan... 2013]. The quality of emissions has been raised through numerous educational programs, as well as promoting proper segregation of waste instead of burning it in heaters and boilers.

\section{Monthly concentration changes of PM10 and PM2.5}

In 2015, the maximum accepted norm of the concentration of PM10 $(50 \mu \mathrm{g} / \mathrm{m} 3)$ was most often exceeded in February (14 days), March (9 days), October (10 days) and November (10 days) (see Figure 3). In those four months, the accepted concentration was exceeded 43 times, that is $80 \%$ of all the days in the year with the exceeded norm. Additionally, the average concentration was the highest in the above-mentioned months: February $-55 \mu \mathrm{g} / \mathrm{m}^{3}$, March $-45 \mu \mathrm{g} / \mathrm{m}^{3}$, October $53 \mu \mathrm{g} / \mathrm{m}^{3}$, November $-49 \mu \mathrm{g} / \mathrm{m}^{3}$. The months with the lowest average concentration of the harmful substances were: April $\left(27 \mu \mathrm{g} / \mathrm{m}^{3}\right)$, May $\left(22 \mu \mathrm{g} / \mathrm{m}^{3}\right)$, June $\left(20 \mu \mathrm{g} / \mathrm{m}^{3}\right)$, July $\left(27 \mu \mathrm{g} / \mathrm{m}^{3}\right)$, December $\left(26 \mu \mathrm{g} / \mathrm{m}^{3}\right)$. In April, the daily accepted norm of the concentration was exceeded 4 times, and in the other months, it was not exceeded at all. The level of concentration of the suspended particulates PM10 and PM2.5 is characterised by a very high degree of interdependence. The value of correlation was: $r=0.93$.

In 2016, the daily norms were exceeded less frequently than in the previous year (see Figure 4). The daily concentration of PM10 was decidedly exceeded most often in January (14 days), which constitutes $24 \%$ of the days in the year when the norm was exceeded. The highest average concentrations were noted in the autumn and winter months: January $\left(52 \mu \mathrm{g} / \mathrm{m}^{3}\right)$, February $\left(34 \mu \mathrm{g} / \mathrm{m}^{3}\right)$, March $\left(36 \mu \mathrm{g} / \mathrm{m}^{3}\right)$, April $\left(33 \mu \mathrm{g} / \mathrm{m}^{3}\right)$, September $\left(41 \mu \mathrm{g} / \mathrm{m}^{3}\right)$, November $\left(38 \mu \mathrm{g} / \mathrm{m}^{3}\right)$, December $\left(40 \mu \mathrm{g} / \mathrm{m}^{3}\right)$. The daily concentration level of PM10 in 2016 was less variable than in 2015 , the coefficient of variation was $\mathrm{V}=57 \%$, while in the previous year it was $\mathrm{V}=73 \%$. The

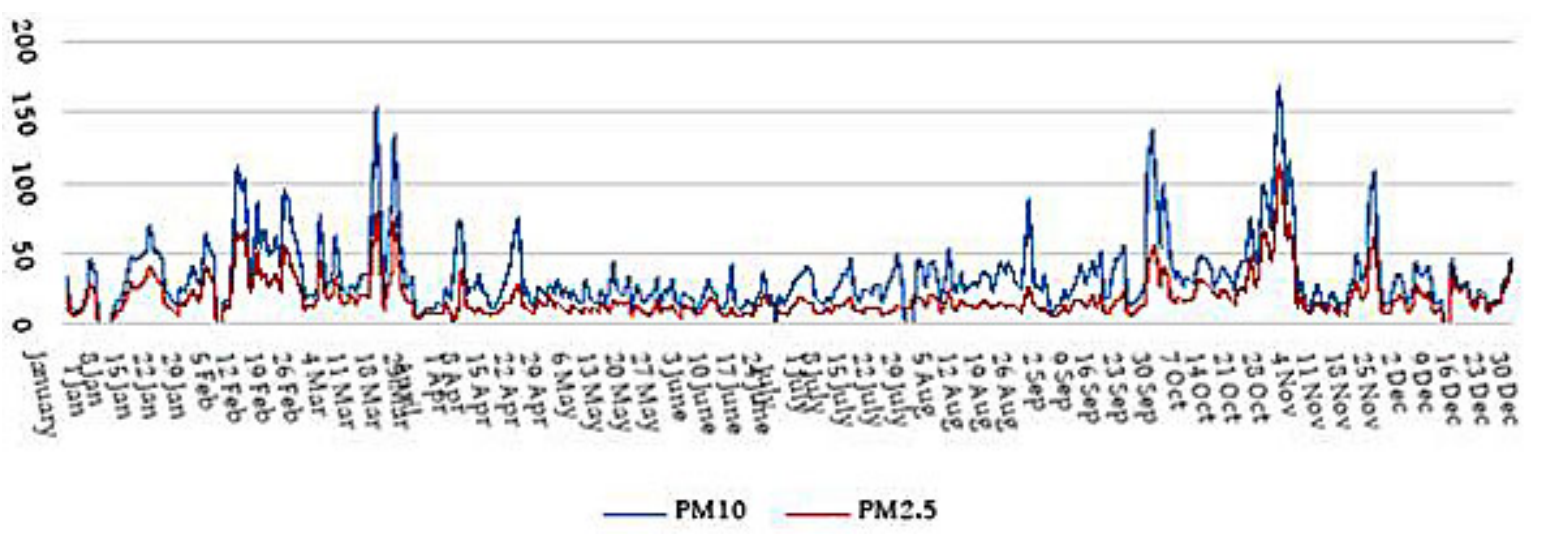

Figure 3. The level of concentration of the suspended particulates PM10 and PM2.5 in $2015\left[\mu \mathrm{g} / \mathrm{m}^{3}\right.$ ] (based on data from the meteorological station on Polanka St. in Poznań) 


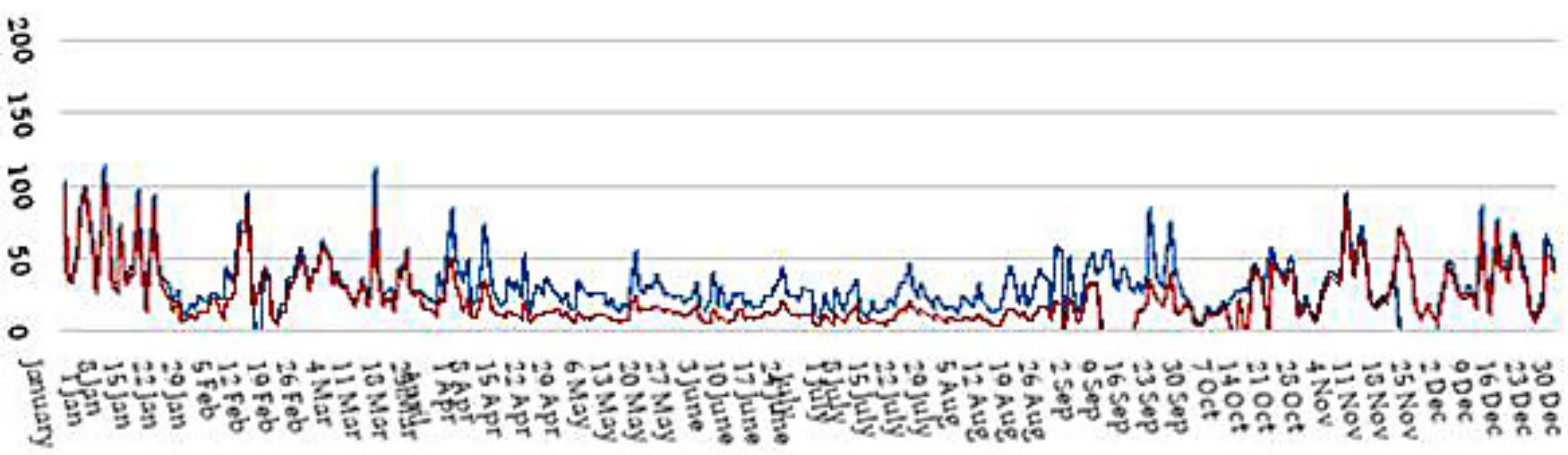

\begin{abstract}
PM10 PM2.5
Figure 4. The level of concentration of the suspended particulates PM10 and PM2.5 in $2016\left[\mu \mathrm{g} / \mathrm{m}^{3}\right]$ (based on data from the meteorological station on Polanka St. in Poznań)
\end{abstract}

concentration level of PM2.5 was again strongly correlated with the concentration level of PM10, with the value of correlation $r=0.92$.

The year 2017 was marked by the highest level of variation of the concentration of PM10, with the coefficient of variation $\mathrm{V}=101 \%$. It was mainly due to the extremely high concentration values in January and February (see Figure 5). In those months the daily accepted norm was most frequently exceeded; in total, on 30 days during the two months, which constitutes $85 \%$ of all the days in the year when the norm was exceeded. The average daily concentration of PM10 in January was $61 \mu \mathrm{g} / \mathrm{m}^{3}$, while in February it was $59 \mu \mathrm{g} / \mathrm{m}^{3}$. In the remaining months, the level of concentration was relatively low, with average monthly values not exceeding 28 $\mu \mathrm{g} / \mathrm{m}^{3}$, and there were 5 days with a higher daily concentration (over $50 \mu \mathrm{g} / \mathrm{m}^{3}$ ). The value of correlation between the concentration of PM10 and PM2.5 was nearly linear with $r=1.00$.
The presented data indicate that the acceptable limits of suspended particulates emission in Poznań were exceeded in the autumn and winter period in 2015-2017. Similarly to the heating season, the produced pollution is most likely causing the highest emissions of the suspended particulates. It is probably the effect of the increased usage of old, low-efficiency heaters, resulting in the high emission of PM10 and PM2.5. The strong correlation between the emission of the suspended particulates and the temperature confirms this assumption. The value of correlation coefficient for PM10 and the temperature was $r=-0.311$, and for PM2.5 and the temperature, it was $r=-0.48$. The air humidity also influences the amount of the suspended particulates. It is noted that the higher the humidity, the higher the concentration of PM10 and PM2.5; however, it is much more visible in the case of PM2.5 $(r=0.29)$, than PM10 ( $r=0.15)$. In light of the above, it is observed that the urban development have changed

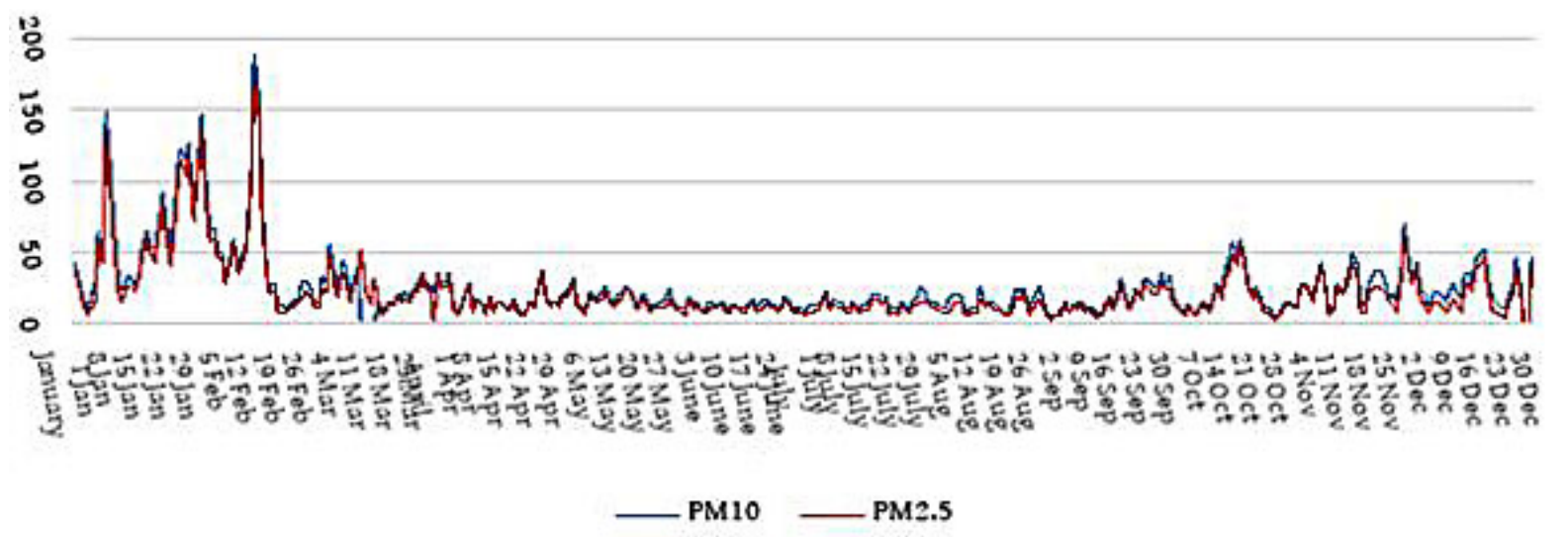

Figure 5. The level of concentration of the suspended particulates PM10 and PM2.5 in 2017 [ $\mu \mathrm{g} / \mathrm{m}^{3}$ ] (based on data from the meteorological station on Polanka St. in Poznań) 
the temperature, wind direction (due to the buildings) and humidity. The weather-influencing factors, together with the traffic and improper heating systems have caused a certain deterioration of the urban living conditions [de Lieto Vollaro et al. 2014; Battista 2017].

The sources of the suspended particulates emissions (transport, energy) in Poznań produce both PM10 and PM2.5, as is indicated by the calculated high correlation coefficient of the emissions.

\section{CONCLUSIONS}

The presented research shows a gradual decrease in the suspended particulates emissions, resulting from the programs that improve the effectiveness and efficiency of the heating installations and the thermomodernisation of the buildings. The public awareness has also increased when it comes to waste management. The extensive train and tram network in Poznań allows for lowering the emissions of PM10 and PM2.5. The annual characteristics of the suspended particulates emissions indicate that the emissions are the highest in the autumn and winter period, which is linked to the heating necessities. The correlation of the emissions and the temperature also confirms that the main sources of the emissions are the inefficient heaters and boilers. Moreover, high humidity is also an adverse weather factor. The water vapor binds with the suspended particulates and it causes them to settle down on the surfaces quicker.

\section{REFERENCES}

1. Battista G. 2017. Analysis of the Air Pollution Sources in the city of Rome (Italy). Energy Procedia, 126, 392-397.

2. Cembrzyńska, J., Krakowiak, E., Brewczyński, P.Z. 2012. Particulate pollution of PM10 and PM2.5 due to strong anthropopressure in Sosnowiec city (in Polish). Medycyna Środowiskowa - Environmental Medicine, 15(4), 31-38.

3. Cieślik, M., Dach, J., Lewicki, A., Smurzyńska, A., Janczak, D., Pawlicka-Kaczorowska, J., Boniecki, P., Cyplik, P., Czekała, W., Joźwiakowski, K. 2016. Methane fermentation of the maize straw silage under meso- and thermophilic conditions. Energy, 115, 1495-1502.

4. Czekała, W., Smurzyńska, A., Cieślik, M., Bon- iecki, P., Kozłowski, K. 2016. Biogas efficiency of selected fresh fruit covered by the russian embargo. Energy and Clean Technologies Conference Proceedings, SGEM 2016, VOL III, Book Series: International Multidisciplinary Scientific GeoConference-SGEM, 227-233.

5. Czekała, W., Dach, J., Dong, R., Janczak, D., Malińska, K., Joźwiakowski, K., Smurzyńska, A., Cieślik, M. 2017. Composting potential of the solid fraction of digested pulp produced by a biogas plant. Biosystems Engineering, 160, 25-29.

6. de Lieto Vollaro, A., de Simone, G., Romagnoli, R., Vallati, A., Bottillo, S. 2014. Numerical study of urban canyon microclimate related to geometrical parameters. Sustainability, 6, 7894-7905.

7. Dreiseidler, A.M., Baumbach, G., Straub, D. 2000. Results of fine particulate matter emission measurements at different industrial plants. Journal of Aerosol Science, Volume 31, Supplement 1, 242-243.

8. Dzikuć, M. 2017. Problems associated with the low emission limitation in Zielona Góra (Poland): Prospects and challenges. Journal of Cleaner Production, 166, 81-87.

9. Du, E., Dong, D., Zeng, X., Sun, Z., Jiang, X., Vriescd, W. 2017. Direct effect of acid rain on leaf chlorophyll content of terrestrial plants in China. Science of The Total Environment, Vol. 605-606, 764-769.

10. Fajczak-Kowalska, A., Ziemiński, P., Rudowska, P. 2017. Sustainable public transportation as a cornerstone of citizen-friendly urban logistics (in Polish). Gospodarka w praktyce i teorii, 1(46), 27-43.

11. Gładka, A., Zatoński, T. 2016. Impact of air pollution on respiratory diseases (in Polish). Kosmos Problemy Nauk Biologicznych, Vol. 65, 4(313), 573-582.

12. SVS 2017. Statistical Vademecum of Local Government (in Polish). Urząd statystyczny w Poznaniu.

13. Kampa, M., Castanas, E. 2008. Human health effects of air pollution. Environmental Pollution, 151(2), 362-367.

14. Lelek, Ł., Kulczycka, J., Lewandowska, A., Zarębska, J. 2016. Life cycle assessment of energy generation in Poland. Int. J. Life Cycle Assess., 21(1), 1-14.

15. Ma, J., Xu, X., Zhao, C., Yan, P. 2012. A review of atmospheric chemistry research in China: photochemical smog, haze pollution, and gas-aerosol interactions. Adv. Atmos. Sci., 29, 1006-1026.

16. Maeda, Y., Morioka, J., Tsujino, Y., Satoh, Y., Zhang, X., Mizoguchi, T., Hatakeyama, S. Material damage caused by acidic air pollution in East Asia. Water Air Soil Poll., 130, 141-150.

17. Mayer H. 1999. Air pollution in cities. Atmospheric Environment, 33, 4029-4037. 
18. McDonald, D.R., Gentner, A.H., Goldstein, R.A. 2013. Harley Long-term trends in motor vehicle emissions in U.S. urban areas. Environ. Sci. Technol., 47, 10022-10031.

19. Mishra, S. 2017. Is smog innocuous? Air pollution and cardiovascular disease. Indian Heart Journal, 69(4), 425-429.

20. Penn, S.L., Boone, S.T., Harvey, B.C., Heiger-Bernays, W., Tripodis, Y., Arunachalam, S., Levy, J.I. 2017. Modeling variability in air pollution-related health damages from individual airport emissions. Environmental Research, 156, 791-800.

21. Environmental Protection Program for the city of Poznań for 2013-2016 with a perspective for 2020 (in Polish). 2013. Poznań, 53-70.

22. Ramanathan, V., Feng, Y. 2009. Air pollution, greenhouse gases and climate change: Global and regional perspectives. Atmospheric Environment, 43(1), 37-50.

23. Roy, J., Ghosh, D., Ghosh, A., Dasgupta, S. 2013. Fiscal instruments: crucial role in financing low carbon transition in energy systems. Curr. Opin. Environ. Sustain., 5, 261-269.

24. Regulation of the Minister of the Environment of 24 August 2012 on certain substances in the air (in Polish).
25. Smurzyńska, A., Dach, J., Szulc, R. 2015. Influence of different slurry treatment technologies for methane emissions after application of slurry to the soil. Acta Scientiarum Polonorum-Formatio Circumiectus, 14(3), 165-174.

26. Son, S-W., Tandon, N.F., Polvani, L.M., Waugh, D.W. 2009. Ozone hole and Southern Hemisphere climate change. Geophys. Res. Lett., 36, L15705.

27. Sosa, B.S., Porta, A., Lerner, J.E.C., Noriega, R.B., Massolo, L. 2017. Human health risk due to variations in PM10-PM2.5 and associated PAHs levels. Atmospheric Environment, 160, 27-35.

28. Sun, Ch., Luo, Y., Li, J. 2018. Urban traffic infrastructure investment and air pollution: Evidence from the 83 cities in China. Journal of Cleaner Production, 172, 488-496.

29. Wang, X., Chen, J., Cheng, T., Zhang, R., Wang, X. 2014. Particle number concentration, size distribution and chemical composition during haze and photochemical smog episodes in Shanghai. Journal of Environmental Sciences, 26(9), 1894-1902.

30. Wang, Ch., Li, Y., Liu, Y. 2018. Investigation of water-energy-emission nexus of air pollution control of the coal-fired power industry: A case study of Beijing-Tianjin-Hebei region, China. Energy Policy, 115, 291-301. 